\title{
PROJECTION OF ANNUAL CROP COEFFICIENTS IN ITALY BASED ON CLIMATE MODELS AND LAND COVER DATA
}

\author{
Mărgărit-Mircea NISTOR ${ }^{1 *}$
}

DOI: 10.21163/GT_2018.132.08

\begin{abstract}
:
Nowadays, a multitude of world changes are coming to affect the ecosystems, urban landscapes, and natural resources. Land use and land cover patterns represent an interactive layer between Earth surface and underground entities which is often consider in the hydrogeological studies. Many factors such as climate parameters and human activities affects the groundwater recharge, quality of water resources and also changes in the hydrologic regime. Crop evapotranspiration plays an essential role in the water balance and water deficit investigations. Here, we use the seasonal crop coefficients to calibrate the annual crop coefficients for the Italian territory. These values could be useful for the temperate zone area. Four stages of annual crop coefficients were set (initial, mid-season, end season, cold season) to perform the calculation of annual crop coefficients. The annual crop coefficients $(\mathrm{AKc})$ have been extracted from the annual ETc. CORINE land cover data and high resolution climate models of potential evapotranspiration (ET0) were the key datasets for AKc projection in Italy. These findings and original maps that we show in the paper represent important tools for the agriculture, environmental, and urban planning.
\end{abstract}

Keywords: land cover, seasons, crop coefficients, crop evapotranspiration, land cover projections, Italy.

\section{INTRODUCTION}

In several cases, the climate change have had negative impact on surface water resources and groundwater (Loàiciga et al., 2000; Parmesan \& Yohe, 2003; Brouyère et al., 2004; Campos et al., 2013; Prăvălie et al., 2014). It was shown that the ecosystems and it's ecolines are very sensitive to climate change, biodiversity and composition can have consistent changes. In addition to climate change, the land cover and land use pattern play an important role in the interface of land and atmosphere.

Slightly changes of land cover may disturb the entire functions of the ecosystems, which preserve the equilibrium in various domain: e.g. effect on water vulnerability in the regional and local hydrology, cultivation patterns in agriculture, and the evapotranspiration regime as a climatic parameter.

\footnotetext{
${ }^{1}$ Nanyang Technological University, School of Civil and Environmental Engineering, 639798, Singapore; margarit@ntu.edu.sg
} 
Both climate and land cover are direct responsible for the evapotranspiration phenomena, fact for which many hydrological studies used the potential evapotranspiration and actual evapotranspiration for water balance and water surplus investigations (Li et al., 2007; Rosenberry et al., 2007; Gowda et al., 2008). The land cover changes on short-term could be detected by satellite images (Angelini et al., 2017), which are now available at high resolution. In the last years, Adamo et al. (2014) predicted the shoreline changes using the coastal erosion model based on altimeters and directional wave spectrum. Rogana \& Chen (2004) have applied the remote sensing to identify and monitor the land cover and land use changes. In their study, the techniques of data collection from sensors, spatial resolution and data processing were discussed. Moreover, geographic information systems (GIS) and image analysis systems, become together strong tools in the land cover changes mapping (Treitz \& Rogan, 2004). However, in this study, we have focused on CORINE Land Cover and Hercules models, because these databases are already validated and available for scientists' community.

A substantial contribution was the FAO Paper no. 56 (Allen et al., 1998) and Allen's work (Allen, 2000) that proposed a complex methodology to calculate the crop evapotranspiration $\left(\mathrm{ET}_{\mathrm{c}}\right)$ and to carry out the $\mathrm{K}_{\mathrm{c}}$ /evapotranspiration rate for different type of crops. In the same years, Grimmond \& Oke (1999) done the measurements of evapotranspiration in various cities from United States and further they calculated the $\mathrm{K}_{\mathrm{c}}$ related not only for crops and plants, but also for urban areas and impervious fractions. Integrating the $\mathrm{K}_{\mathrm{c}}$ in the formula of $\mathrm{ET}_{\mathrm{c}}$, Nistor et al. (2017) calculated the $\mathrm{ET}_{\mathrm{c}}$ for regional scale in four seasons for the Pannonian basin. They extracted the $\mathrm{K}_{\mathrm{c}}$ from the CORINE Land Cover database and, considering the growth of crops period they divided the year months in the crop calendar. Thus, initial, mid-seasons, end season and cold seasons were the main periods for which they have calculated the seasonal $\mathrm{ET}_{\mathrm{c}}$. Summing the values of seasonal $\mathrm{ET}_{\mathrm{c}}$, the total annual $\mathrm{ET}_{\mathrm{c}}$ was found.

The aim or our work was to complete the spatial distribution of seasonal $\mathrm{K}_{\mathrm{c}}$ related to four stages of crop calendar and to calculate the annual $\mathrm{K}_{\mathrm{c}}$ for the Italian territory. $\mathrm{We}$ choose this land because is composed by a heterogeneous landscape including almost all relief types and extends on more than 10 degrees in latitude, which implies an advantage for the annual $\mathrm{K}_{\mathrm{c}}$ calculation in temperate zone. Moreover, Italian territory has a large coastal zone, with a diversity of vegetation cover, but also and the climate is complex in Italy. The findings carried out through our methodology are a huge contribution for climatologist and hydrogeologists due to a final product map annual $\mathrm{K}_{\mathrm{c}}$ for present and future.

\section{STUDY AREA}

Italian territory extends from $36^{\circ} 38^{\prime}$ to $47^{\circ} 4^{\prime}$ ' North and $6^{\circ} 38^{\prime}$ to $18^{\circ} 32^{\prime}$ ' East (GCS_WGS_1984 Projection) and is located in south of Europe (Fig. 1). Italy is a Mediterranean country, with a large coastal lines, various orography and complex climate. Thus, the eastern coast is bordered by Adriatic sea from North to South, the South and southeastern sides of the country are mainly bordered by Ionian Sea and Mediterranean Sea, when the northwestern and western sides of Italy are bordered by Ligurian Sea respective Tyrrhenian Sea. Attached to Italy are also Sicily and Sardinia Islands, but also many small islands. 

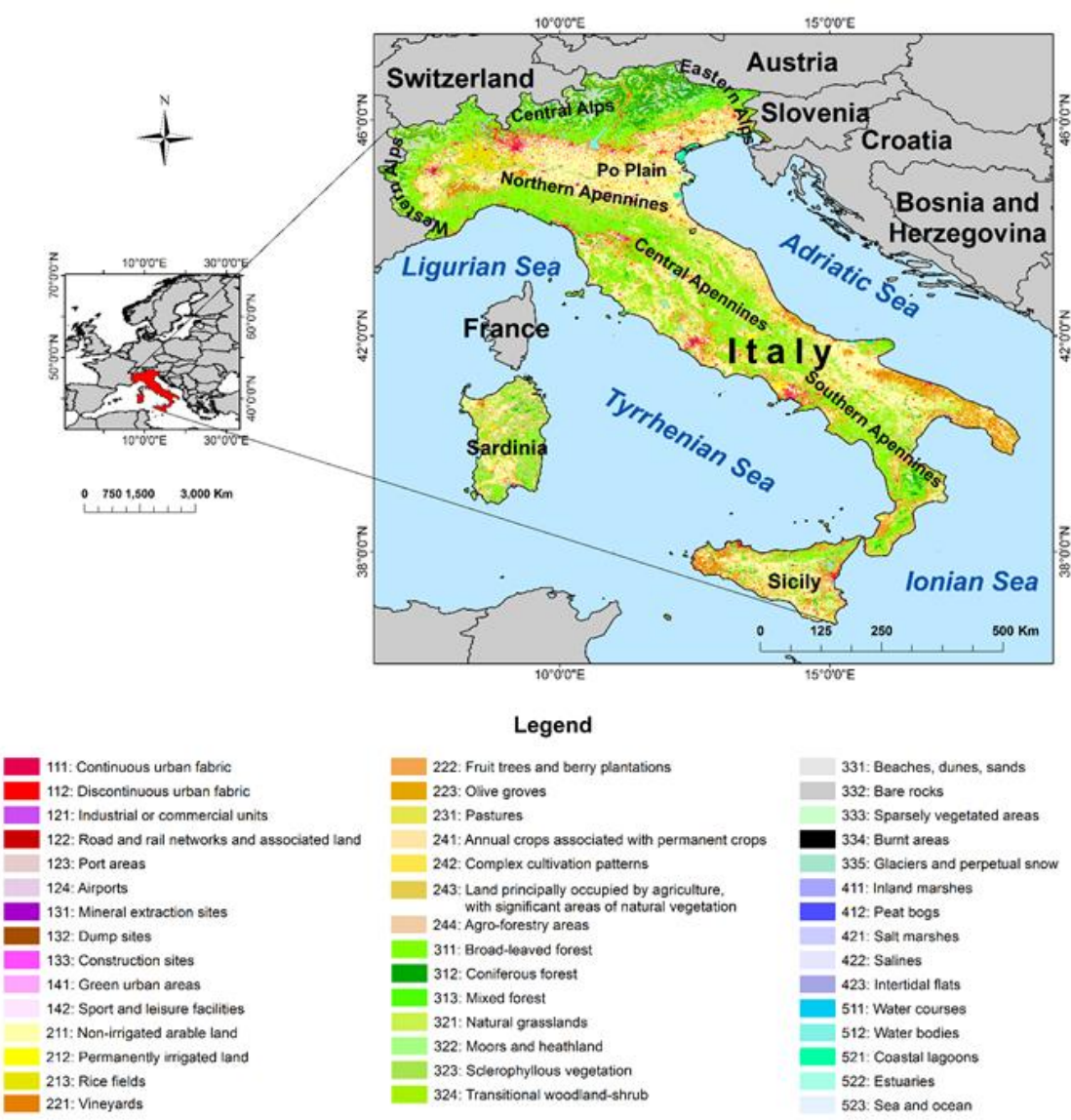

Legend

\begin{tabular}{|l|l|}
\hline 222: Fruit trees and berry plantations & 331: Beaches, dunes, sands \\
\hline 223: Olive groves & 332: Bare rocks \\
231: Pastures & 333: Sparsely vegetated areas \\
\hline 241: Annual crops associated with permanent crops & 334: Burnt areas \\
\hline 242: Complex cultivation patterns & 335: Glaciers and perpetual snow \\
\hline 243: Land principally occupied by agriculture, & 411: Inland marshes \\
with significant areas of natural vegetation & 412: Peat bogs \\
\hline 244: Agro-forestry areas & 421: Salt marshes \\
\hline 311: Broad-leaved forest & 422: Salines \\
\hline 312: Coniferous forest & 423: Intertidal flats \\
\hline 313: Moxed forest & 511: Water courses \\
\hline 321: Natural grasslands & 512: Water bodies \\
\hline 322: Mors and heathland & 521: Coastal lagoons \\
\hline 323: Sclerophyllous vegetation & 522: Estuaries \\
\hline 324: Transitional woodland-shrub & 523: Sea and ocean \\
\hline
\end{tabular}

Fig. 1. Location of the Italy on the Europe map (left) and land cover of the Italian territory (right).

Regarding the relief of the Italy, the major mountain belts are the Alps Mountains in North (Western Alps, Central Alps, and Eastern Alps) and Apennines Mountains (Northern Apennines, Central Apennines, and Southern Apennines) that extends from northwestern to southeastern through the central part of the Italian Peninsula. The main lowlands are Po Plain and Po River Delta, located in North sides of the country, but also the Adriatic coast represents the realm with lows elevations.

From climate point of view, the $\mathrm{Cfa}$ and $\mathrm{Cfb}$ are the main climate in the North of the country (Kottek et al., 2006) with Csa climate in the South. The mean annual temperature for the actual period in the study area ranged from $-0.5{ }^{\circ} \mathrm{C}$ in North to $18.4{ }^{\circ} \mathrm{C}$ in South. The mean annual precipitation in the present period exceeds $1800 \mathrm{~mm} \mathrm{year}^{-1}$ in many locations of Alps and Northern Apennines and the maximum values reach $2100 \mathrm{~mm} \mathrm{year}^{-1}$ in the Northern Apennines. The $\mathrm{ET}_{0}$ in Italy ranged from $367 \mathrm{~mm}$ up to $927 \mathrm{~mm}$. The maximum values of $\mathrm{ET}_{\mathrm{c}}(1299 \mathrm{~mm})$ are found in the South of the Italy, but also the values over 1200 
$\mathrm{mm}$ of $\mathrm{ET}_{\mathrm{c}}$ are found in Sicily and West side of Sardinia. The highest value of $\mathrm{ET}_{\mathrm{c}}$ in that area is influenced by the high temperatures and high $\mathrm{K}_{\mathrm{c}}$ of vegetation (e.g. broad-leaved forest). The adapted vegetation at orography and climate were identified in Italy. In mountains areas the main covers are coniferous and mixed forest which included species as oak (Quercus), beech (Fagus), elms (Ulmus), and hornbeam (Carpinus) (European Environment Agency, 2007), pasture and transnational woodland and shrubs. The lowlands and plains are mainly covered by hay, herbaceous vegetation and agricultural lands. In the hilly areas and in the meadows along rivers are presents more broad-leaved forests and shrubs. The coastal areas are predominantly with Mediterranean vegetation as Italian stone pine (Pinus pinea), green areas, and sclerophyllous vegetation. On the coast zone are also located the ports areas, the lagoons and marshes.
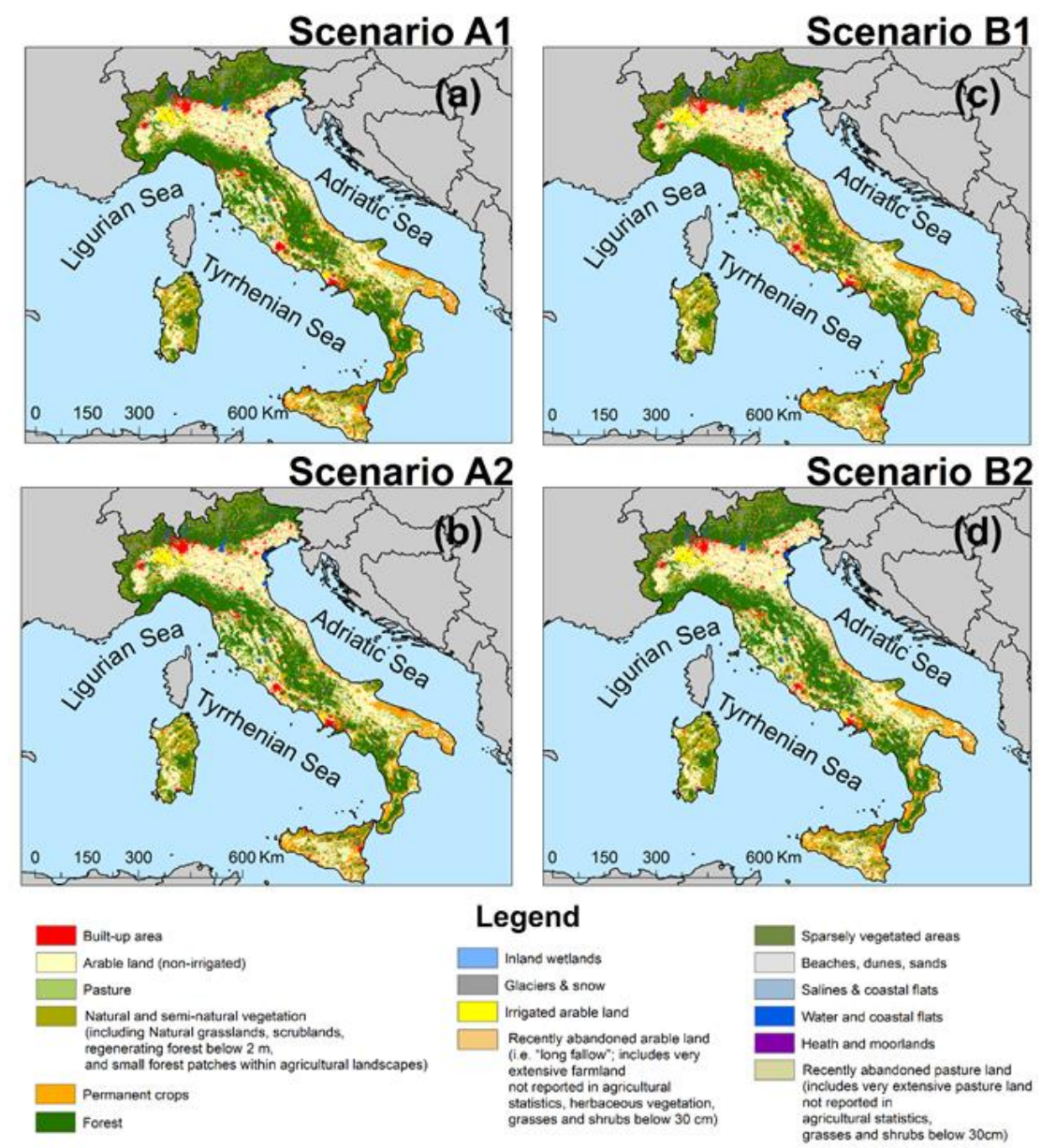

Fig. 2. Land cover projections of Italy. (a) Scenario A1. (b) Scenario A2. (c) Scenario B1. (d) Scenario B2. Source: Sustainable futures for Europe's HERitage in CULtural landscapES" project (http://www.hercules-landscapes.eu/). 


\section{MATERIALS AND METHODS}

\subsection{CORINE land cover data}

Raster data with $250 \mathrm{~m}$ spatial resolution of CORINE Land Cover 2012 served to identify represent the land type categories in Italy for the present period. This database was elaborated by Copernicus Land Monitoring Services (2012) and cover the northern, southern, western and central sides of Europe.

Dynamic spatial changes of the land use and land cover for the future period have been depicted using the Hercules models carried out in the "Sustainable futures for Europe's HERitage in CULtural landscapES" project, GA no. 603447 (Schulp et al., 2015). Using four scenarios, Schulp et al. (2015) projected the land cover of Europe by 2040 based on macro-economic and land use models for which they set fourteen trajectories in the land trend considering the urbanization, agriculture and forestry.

The raster data of future Hercules models are available on website (http://www.hercules-landscapes.eu/) while the procedure of the trajectories, indices and mapping cultural landscapes is highlighted in the Report no. 1 off the Hercules project (Schulp et al., 2015). Four scenarios as A1, A2, B1, and B2 in sixteen classes (Fig. 2) built for 2040 were used for the present paper to represent the spatial distribution of seasonal $\mathrm{K}_{\mathrm{c}}$.

\subsection{Seasonal crop coefficients $(\mathrm{Kc})$}

According to Allen et al. (1998) and Grimmond \& Oke (1999), for each land cover type was assigned a certain crop coefficient $\left(\mathrm{K}_{\mathrm{c}}\right)$ value. Based on these values, the $\mathrm{ET}_{\mathrm{c}}$ calculation for four season and annual periods were done.

Allen et al. (1998) have mentioned tested values and a detailed analyzed $\mathrm{K}_{\mathrm{c}}$ for various climate zones (e.g. Tropics, Temperate, and Mediterranean) in the Food and Agriculture Organization report. The $\mathrm{K}_{\mathrm{c}}$ related to the urban areas and bare soil have been calculated and published by Grimmond \& Oke (1999). Four stages of crop growth and specified $\mathrm{K}_{\mathrm{c}}$ for have been considered in this study, as follow: initial season $\left(\mathrm{K}_{\mathrm{c} \text { ini }}\right)$ during the March, April, May; mid-season $\left(\mathrm{K}_{\mathrm{c} \text { mid }}\right)$ during June, July, August; end season ( $\mathrm{K}_{\mathrm{c} \text { end }}$ ) during September and October; cold season $\left(\mathrm{K}_{\mathrm{c}}\right.$ cold) during January, February, November, and December. Here, we adopt the Nistor et al. (2017) methodology to illustrate the spatial distribution of $K_{c}$ in Italy and to carry out the annual crop coefficients $\left(\mathrm{AK}_{\mathrm{c}}\right)$. At regional scale, due to the overlap of growth crops calendar, the scientists insert this stage in the initial season (Nistor et al., 2017). The standard $\mathrm{K}_{\mathrm{c}}$ values for initial season, mid-season, end season, and cold season related to the present and future are reported in the Table 1 , respective Table 2 . 
Table 1. Corine Land Cover classes and representative seasonal Kc coefficients for the present in Italian territory

\begin{tabular}{|c|c|c|c|c|c|}
\hline & Corine Land Cover & $\mathrm{Kc}$ ini season & Kc mid season & Kc end season & Kc cold season \\
\hline CLC code 2012 & CLC Description & Kclc & Kclc & Kclc & Kclc \\
\hline 111 & Continous urban fabric & 0.2 & 0.4 & 0.25 & - \\
\hline 112 & Discontinuous urban fabric & 0.1 & 0.3 & 0.2 & - \\
\hline 121 & Industrial or commercial units & 0.2 & 0.4 & 0.3 & - \\
\hline 122 & Road and rail networks and associated land & 0.15 & 0.35 & 0.25 & - \\
\hline 123 & Port areas & 0.3 & 0.5 & 0.4 & - \\
\hline 124 & Airports & 0.2 & 0.4 & 0.3 & - \\
\hline 131 & Mineral extraction sites & 0.16 & 0.36 & 0.26 & - \\
\hline 132 & Dump sites & 0.16 & 0.36 & 0.26 & - \\
\hline 133 & Construction sites & 0.16 & 0.36 & 0.26 & - \\
\hline 141 & Green urban areas & 0.12 & 0.32 & 0.22 & - \\
\hline 142 & Sport and leisure facilities & 0.1 & 0.3 & 0.2 & - \\
\hline 211 & Non-irrigated arable land & 1.1 & 1.35 & 1.25 & - \\
\hline 212 & Permanently irrigated land & 1.2 & 1.45 & 1.35 & - \\
\hline 213 & Rice fields & 1.05 & 1.2 & 0.6 & - \\
\hline 221 & Vineyards & 0.3 & 0.7 & 0.45 & - \\
\hline 222 & Fruit trees and berry plantations & 0.3 & 1.05 & 0.5 & - \\
\hline 223 & Olive groves & 0.65 & 0.7 & 0.65 & 0.5 \\
\hline 231 & Pastures & 0.4 & 0.9 & 0.8 & - \\
\hline 241 & $\begin{array}{l}\text { Annual crops associated with permanent } \\
\text { crops }\end{array}$ & 0.5 & 0.8 & 0.7 & - \\
\hline 242 & Complex cultivation patterns & 1.1 & 1.35 & 1.25 & - \\
\hline 243 & $\begin{array}{l}\text { Land principally occupied by agriculture, with } \\
\text { significant areas of natural vegetation }\end{array}$ & 0.7 & 1.15 & 1 & - \\
\hline 244 & Agro-forestry areas & 0.9 & 1.1 & 1.05 & 0.3 \\
\hline 311 & Broad-leaved forest & 1.3 & 1.6 & 1.5 & 0.6 \\
\hline 312 & Coniferous forest & 1 & 1 & 1 & 1 \\
\hline 313 & Mixed forest & 1.2 & 1.5 & 1.3 & 0.8 \\
\hline 321 & Natural grasslands & 0.3 & 1.15 & 1.1 & - \\
\hline 322 & Moors and heathland & 0.8 & 1 & 0.95 & - \\
\hline 323 & Sclerophyllous vegetation & 0.25 & 0.9 & 0.8 & - \\
\hline 324 & Transitional woodland-shrub & 0.8 & 1 & 0.95 & - \\
\hline 331 & Beaches, dunes, sands & 0.2 & 0.3 & 0.25 & - \\
\hline 332 & Bare rocks & 0.15 & 0.2 & 0.05 & - \\
\hline 333 & Sparsely vegetated areas & 0.4 & 0.6 & 0.5 & - \\
\hline 334 & Burnt area & 0.1 & 0.15 & 0.05 & - \\
\hline 335 & Glaciers and perpetual snow & 0.48 & 0.52 & 0.52 & 0.48 \\
\hline 411 & Inland marshes & 0.15 & 0.45 & 0.8 & - \\
\hline 412 & Peat bogs & 0.1 & 0.4 & 0.75 & - \\
\hline 421 & Salt marshes & 0.1 & 0.3 & 0.7 & - \\
\hline 422 & Salines & 0.1 & 0.15 & 0.05 & - \\
\hline 423 & Intertidal flats & 0.3 & 0.7 & 1.3 & - \\
\hline 511 & Water courses & 0.25 & 0.65 & 1.25 & - \\
\hline 512 & Water bodies & 0.25 & 0.65 & 1.25 & - \\
\hline 521 & Coastal lagoons & 0.3 & 0.7 & 1.3 & - \\
\hline 522 & Estuaries & 0.25 & 0.65 & 1.25 & - \\
\hline 523 & Sea and ocean & 0.4 & 0.8 & 1.4 & - \\
\hline
\end{tabular}

$\mathrm{Kc}$ - crop coefficient for plants, Ks - evaporation coefficient for bare soils, Ku - crop coefficient for urban areas, Kw evaporation coefficient for open water, Kclc - crop coefficient for land cover. Source: From Allen et al. (1998); Nistor et al. (2017) 


\begin{tabular}{|c|c|c|c|c|c|c|}
\hline \multicolumn{3}{|r|}{ Corine Land Cover } & \multicolumn{4}{|c|}{$\mathrm{Kc}$ ini season $\mathrm{Kc}$ mid season $\mathrm{Kc}$ end seasor $\mathrm{Kc}$ cold seasor } \\
\hline $\begin{array}{l}\text { CLC code } \\
2012\end{array}$ & $\begin{array}{c}\text { CLC } \\
\text { projection } \\
\text { code }\end{array}$ & CLC Description & Kclc & Kclc & Kclc & Kclc \\
\hline 133 & 0 & Built-up area & 0.16 & 0.36 & 0.26 & - \\
\hline 211 & 1 & Arable land (non-irrigated) & 1.1 & 1.35 & 1.25 & - \\
\hline 231 & 2 & Pasture & 0.4 & 0.9 & 0.8 & - \\
\hline $\begin{array}{l}321 \text { and } \\
324\end{array}$ & 3 & $\begin{array}{l}\text { Natural and semi-natural vegetation (including Natural grasslands, } \\
\text { scrublands, regenerating forest below } 2 \mathrm{~m} \text {, and small forest patches } \\
\text { within agricultural landscapes) }\end{array}$ & 0.45 & 1.1 & 1 & - \\
\hline 411 & 4 & Inland wetlands & 0.15 & 0.45 & 0.8 & - \\
\hline 335 & 5 & Glaciers and snow & 0.48 & 0.52 & 0.52 & 0.48 \\
\hline 212 & 6 & Irrigated arable land & 1.2 & 1.45 & 1.35 & - \\
\hline 321 & 7 & $\begin{array}{l}\text { Recently abandoned arable land (i.e. "long fallow"; includes very } \\
\text { extensive farmland not reported in agricult ural statistics, herbaceous } \\
\text { veget ation, grasses and shrubs below } 30 \mathrm{~cm} \text { ) }\end{array}$ & 0.3 & 1.15 & 1.1 & - \\
\hline 241 & 8 & Permanent crops & 0.5 & 0.8 & 0.7 & - \\
\hline 313 & 10 & Forest & 1.2 & 1.5 & 1.3 & 0.8 \\
\hline 333 & 11 & Sparsely vegetated areas & 0.4 & 0.6 & 0.5 & - \\
\hline 331 & 12 & Beaches, dunes and sands & 0.2 & 0.3 & 0.25 & - \\
\hline 422 & 13 & Salines & 0.1 & 0.15 & 0.05 & - \\
\hline 123 and 521 & 14 & Water and coastal flats & 0.3 & 0.7 & 1.3 & - \\
\hline 322 & 15 & Heathland and moorlands & 0.8 & 1 & 0.95 & - \\
\hline $\begin{array}{c}231 \text { and } \\
324\end{array}$ & 16 & $\begin{array}{l}\text { Recently abandoned pasture land (includes very extensive pasture } \\
\text { land not reported in agricultural statistics, grasses and shrubs below } \\
30 \mathrm{~cm} \text { ) }\end{array}$ & 0.6 & 1 & 0.9 & - \\
\hline
\end{tabular}

$\mathrm{Kc}$ - crop coefficient for plants, Ks - evaporation coefficient for bare soils, Ku - crop coefficient for urban areas, Kw - evaporation coefficient for open water, Kclc - crop coefficient for land cover. Source: From Allen et al. (1998); Nistor et al. (2017)

\subsection{Climate data}

Mean monthly air temperature models related to 2011 to 2040 served to carried out the seasonal $\mathrm{ET}_{0}$ in the present study and to calculate the seasonal and annual $\mathrm{ET}_{\mathrm{c}}$. The climate models are in raster grid format at very high spatial resolution with a temporal average of 30 years. Based on the ANUSplin software, Hamann et al. (2013) have completed the air temperature models for Europe. These models are courtesy by Andreas Hamann from Alberta University, Canada. The climate models were generated using the ClimateEU v4.63 software package (see http://tinyurl.com/ClimateEU) and followed the methodology described by Hamann et al. (2013).

\subsection{Annual crop evapotranspiration $\left(\mathbf{E T}_{\mathbf{c}}\right)$ and annual crop coefficient $\left(\mathrm{AK}_{\mathrm{c}}\right)$}

The $\mathrm{AK}_{\mathrm{c}}$ is the ratio expression of $\mathrm{ET}_{\mathrm{c}}$ and $\mathrm{ET}_{0}$. Based on the seasonal values of $\mathrm{K}_{\mathrm{c}}$ and climate data, the seasonal and annual $\mathrm{ET}_{\mathrm{c}}$ have been calculated. Firstly, for the each set season was performed the $\mathrm{ET}_{0}$ using the Thornthwaite (1948) method (Eq. 1). By multiplying the $\mathrm{ET}_{0}$ of season $\mathrm{K}_{\mathrm{c}}$, the $\mathrm{ET}_{\mathrm{c}}$ related to the four seasons were calculated (Eqs. 4-7). The annual $\mathrm{ET}_{\mathrm{c}}$ is the sum of initial $\mathrm{ET}_{\mathrm{c}}$, mid-season $\mathrm{ET}_{\mathrm{c}}$, end season $\mathrm{ET}_{\mathrm{c}}$ and cold season $\mathrm{ET}_{\mathrm{c}}\left(\mathrm{Eq}\right.$. 8). Divided the annual $\mathrm{ET}_{\mathrm{c}}$ at the $\mathrm{ET}_{0}$, the $\mathrm{AK}_{\mathrm{c}}(\mathrm{Eq}$. 9) was found for the present and further, implemented for the future scenarios. Further, from the annual $\mathrm{ET}_{\mathrm{c}}$ and $\mathrm{ET}_{0}$, the average value of $\mathrm{AK}_{\mathrm{c}}$ for each land cover type was extracted. Using the pinpoint verification on the Italian map, the specific value of the $\mathrm{AK}_{\mathrm{c}}$ were assigned to the respective land cover type. 
where:

$$
\begin{gathered}
E T_{0}=16\left(\frac{10 T_{i}}{I}\right)^{\alpha} \\
\mathrm{I}=\sum_{i=1}^{12}\left(\frac{T_{i}}{5}\right)^{1.514}
\end{gathered}
$$

$\mathrm{ET}_{0}$ monthly potential evapotranspiration $[\mathrm{mm}]$

$\mathrm{T}_{\mathrm{i}}$ average monthly temperature $\left[{ }^{\circ} \mathrm{C}\right], \mathrm{ET}_{0}=0$ if $\overline{\mathrm{Tm}}<0$

I heat index (Eq.(2))

$\alpha \quad$ complex function of heat index (Eq. (3))

where:

$$
\alpha=6.75 \times 10^{-7} \mathrm{I}^{3}-7.71 \times 10^{-5} \mathrm{I}^{2}+1.7912 \times 10^{-2} \mathrm{I}+0.49239
$$

I annual heat index

$$
\begin{gathered}
E T_{\text {c ini }}=E T_{0 \text { ini }} \times K_{\text {c ini }} \\
E T_{c \text { mid }}=E T_{0 \text { mid }} \times K_{\text {c mid }} \\
E T_{\text {c end }}=E T_{0 \text { end }} \times K_{\text {c end }} \\
E T_{c \text { cold }}=E T_{0 \text { cold }} \times K_{c \text { cold }} \\
\text { Annual } E T_{c}=E T_{\text {c ini }}+E T_{\text {c mid }}+E T_{\text {clate }}+E T_{c \text { cold }} \\
A K c=\frac{E T c \text { annual }}{E T 0 \text { annual }}
\end{gathered}
$$
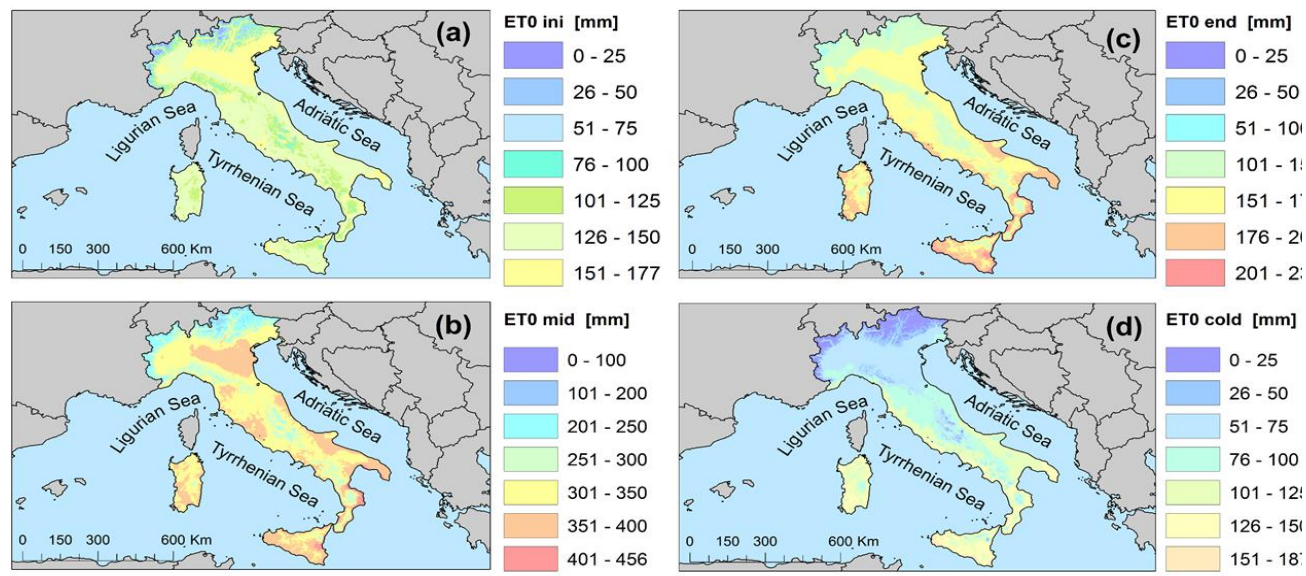

ETO cold [mm]

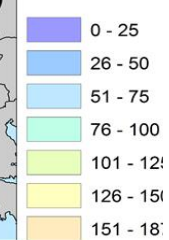

Fig. 3. Spatial distribution of seasonal $E T_{0}$ in Italy. (a) $E T_{0}$ ini for the initial season. (b) $E T_{0}$ mid for the mid-season. (c) ETo end for the end season. (d) ET0 cold for the cold season. 

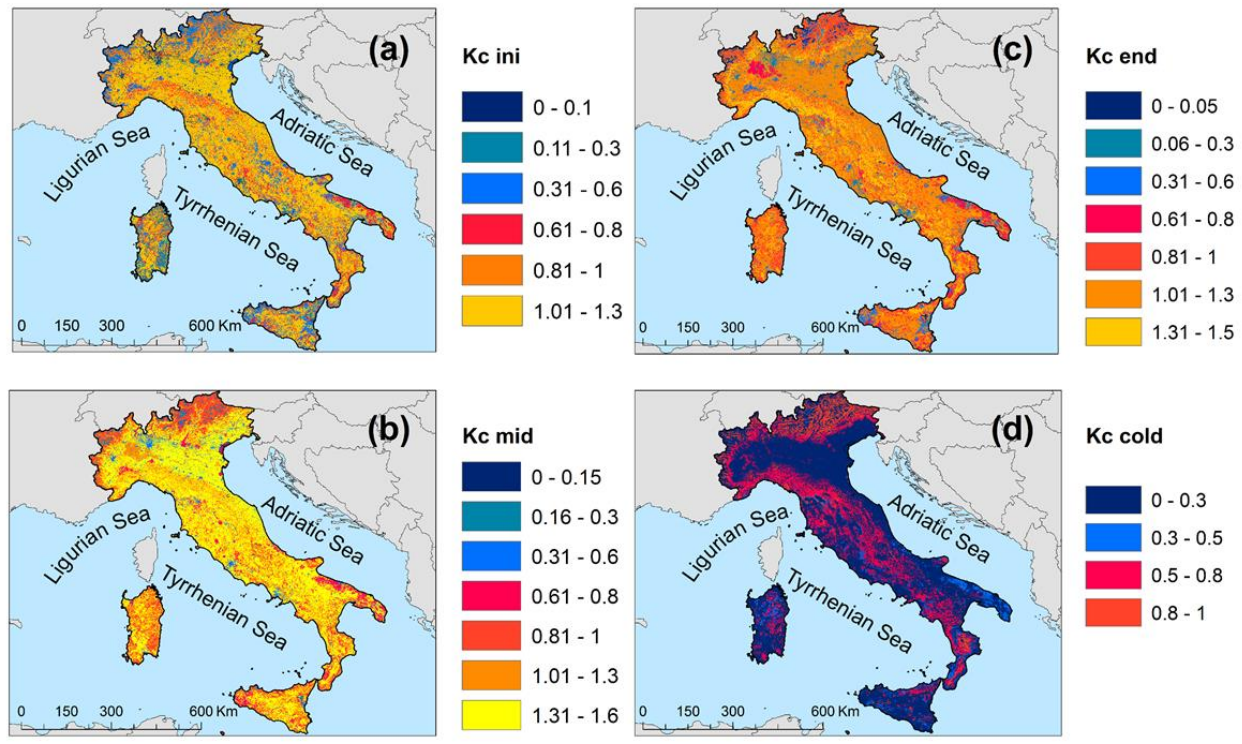

Fig. 4. Spatial distribution of $K_{c}$ in Italy related to the present land cover. (a) $K_{c}$ ini for the initial season. (b) $\mathrm{K}_{\mathrm{c} \text { mid }}$ for the mid-season season. (c) $\mathrm{K}_{\mathrm{c}}$ end for the end season.

(d) $\mathrm{K}_{\mathrm{c} \text { cold }}$ for the cold season.

\section{RESULTS}

Figure 3 depicts the seasonal $\mathrm{ET}_{0}$ in Italy, carried out from the monthly $\mathrm{ET}_{0}$. For the initial season, the $\mathrm{ET}_{0}$ varies from 0 to $177 \mathrm{~mm}$, the maximum values were found in the Po Plain and southeastern sides of Italy, on the coastal area. The mid-season $\mathrm{ET}_{0}$ ranges from 0 to $456 \mathrm{~mm}$, with the several places where the values exceed $300 \mathrm{~mm}$. These sides overlap to Po Plain, coastal areas, central sides of the country and to the Sicily and Sardinia Islands. The values of the $\mathrm{ET}_{0}$ in the end season varies from 0 to $230 \mathrm{~mm}$, the southern parts and the islands are the main land with the high $\mathrm{ET}_{0}$. As we expected, the cold season illustrates lower values of $\mathrm{ET}_{0}$, especially in the North of Italy. In the Central Apennines, northern plains, and in the Alps regions the $\mathrm{ET}_{0}$ fall below $75 \mathrm{~mm}$. In the South, South-East, and South-West, but also in the Sicily and Sardinia Islands, the ET 0 register values above 100 $\mathrm{mm}$ in the cold season. In aim to calibrate the $\mathrm{AK}_{\mathrm{c}}$ for the Italian territory, an detailed analysis of the $\mathrm{K}_{\mathrm{c}}$ spatial distribution were done. Thus, the $\mathrm{K}_{\mathrm{c} \text { ini }}$ varies in the present period from 0 to 1.3 showing a large part of Italy with high coefficient. In the northern sides, excepting the Alps area and cities, the $\mathrm{K}_{\mathrm{c}}$ register values above 1 . The same trend is also on the Tyrrhenian and Adriatic coast, while in the South of Italy the values are around $0.81-1$ in most of the territory, and fall below 0.6 in South of Sardinia, West and East of Sicily. The $K_{c}$ mid ranges from 0 to 1.6 and indicates high values in the Po Plain, northern and eastern coast, in central and south-central Italy, and on western coast. The southeastern, southern and northern parts of Italy shows values between 0.61 and 1 . The most part of Sicily and Sardinia are covered by lands with values of 0.61 to 1.3 for $\mathrm{K}_{\mathrm{c} \text { mid }}$, but there are 
also values which exceed 1.3. In the end season the $\mathrm{K}_{\mathrm{c}}$ end varies from 0 to 1.5 and the major part of territory has values between 0.81 and 1.3. The North of Italy, especially in the Alps Mountains, but also around the big cities, southeastern sides of country, West and East of Sicily the $\mathrm{K}_{\mathrm{c}}$ end fall below 0.6. During the cold season, 0.3 and less values are predominantly in the Italian land. In this season, opposite to the others, the Alps, Northern Apennines, and Central Apennines, and elevated parts of Sicily and Sardinia indicates highest values of the $\mathrm{K}_{\mathrm{c}}$ cold due to the presence of the forest cover, which has the high evapotranspiration rate also in the cold seasons. Figure 4 illustrates the $K_{c}$ spatial distribution in Italy during the four seasons related to the present period.
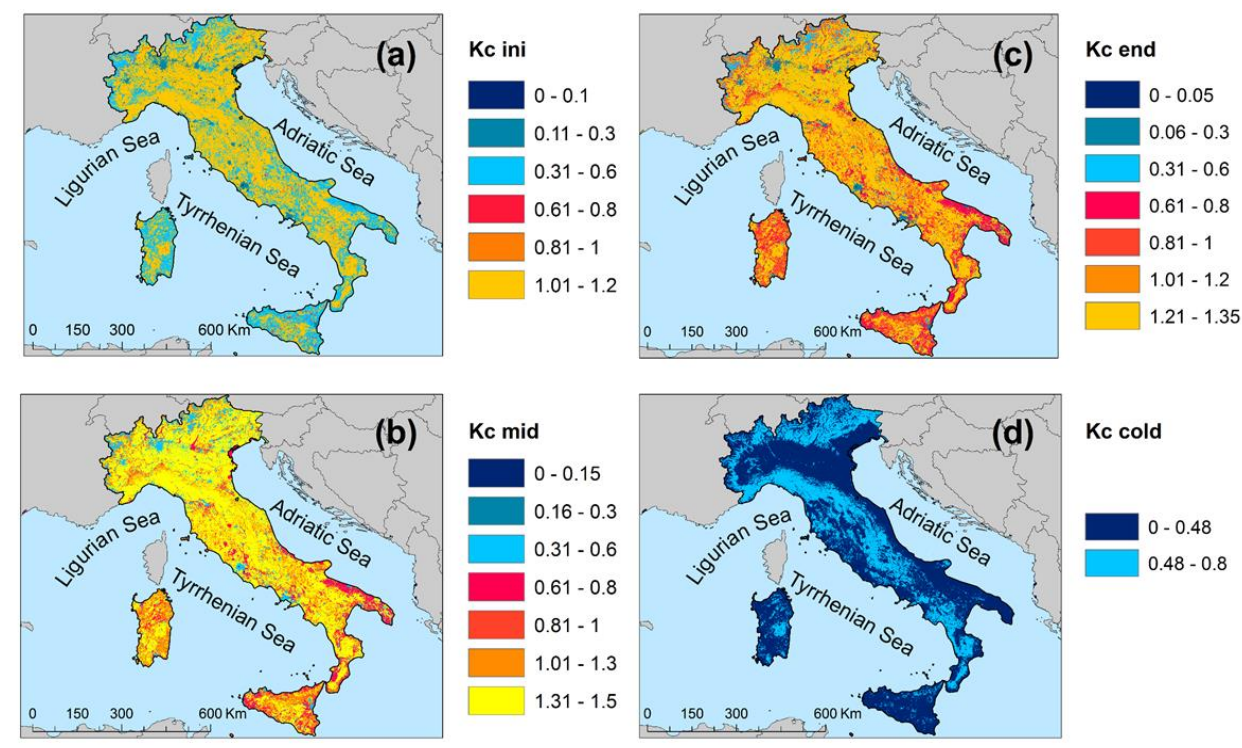

Fig. 5. Spatial distribution of $K_{c}$ in Italy related to the projection of scenario

A1. (a) $K_{c \text { ini }}$ for the initial season. (b) $K_{c}$ mid for the mid-season season. (c) $K_{c}$ end for the end season. (d) $\mathrm{K}_{\mathrm{c} \text { cold }}$ for the cold season.

The future projection of the land cover indicates slightly differences of the $\mathrm{K}_{\mathrm{c}}$ pattern for all seasons due to the simplified land cover classes carried out for 2040 . The $\mathrm{K}_{\mathrm{c} \text { ini }}$ varies in the future from 0 to 1.2 with values between 1 and 1.2 in the northern and inside central peninsula sides, while on the coastal areas, major land of Sicily and Sardinia, and Alps Mountains the values of $\mathrm{K}_{\mathrm{c} \text { ini }}$ ranges from 0.11 to 0.6 . The $\mathrm{K}_{\mathrm{c}}$ in the mid-season increase up to 1.5 and shows large parts of Italian territory with $\mathrm{K}_{\mathrm{c} \text { mid }}$ values over 1.3. These values extends in the North of the country, central and South of the Italian Peninsula. Southeastern and some southern sides of Italy, western, northern, and eastern parts of Sicily, central and North of Sardinia has medium values of $K_{c \text { mid }}(0.6$ to 1$)$. The $K c$ end varies for the future scenarios from 0 to 1.35 , with elevated values ( 1 to 1.35 ) in the central and northern areas of Italy, while the southern areas of Italy, Sicily and Sardinia are cover more by land with Kc end values between 0.6 and 1 . 
The lowest values are located in the elevated mountains and surrounding the large urban areas and in the metropolitan area of the capital. In the cold season, the $\mathrm{K}_{\mathrm{c} \text { cold }}$ illustrates the lowest values of evapotranspiration rate and, more than this, only values below 1 .
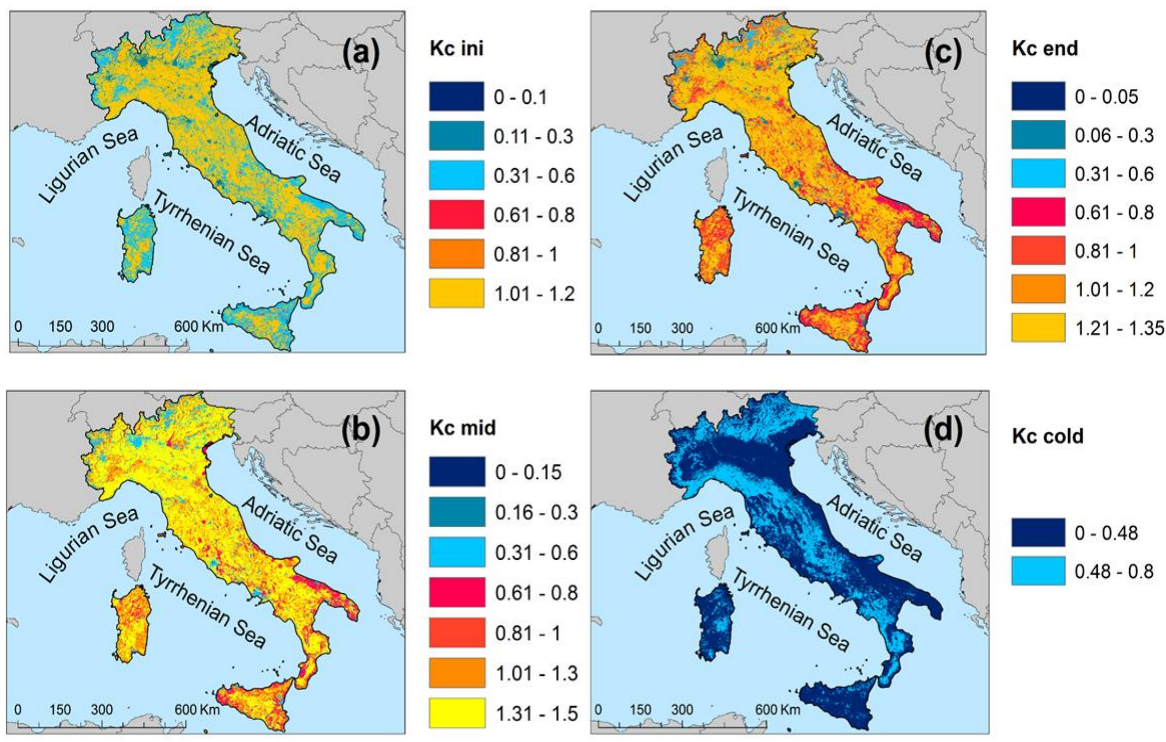

Fig. 6. Spatial distribution of $K_{c}$ in Italy related to the projection of scenario $A 2$. (a) $K_{c}$ ini for the initial season. (b) $K_{c}$ mid for the mid-season season. (c) $K_{c}$ end for the end season.

(d) $\mathrm{K}_{\mathrm{c} \text { cold }}$ for the cold season.
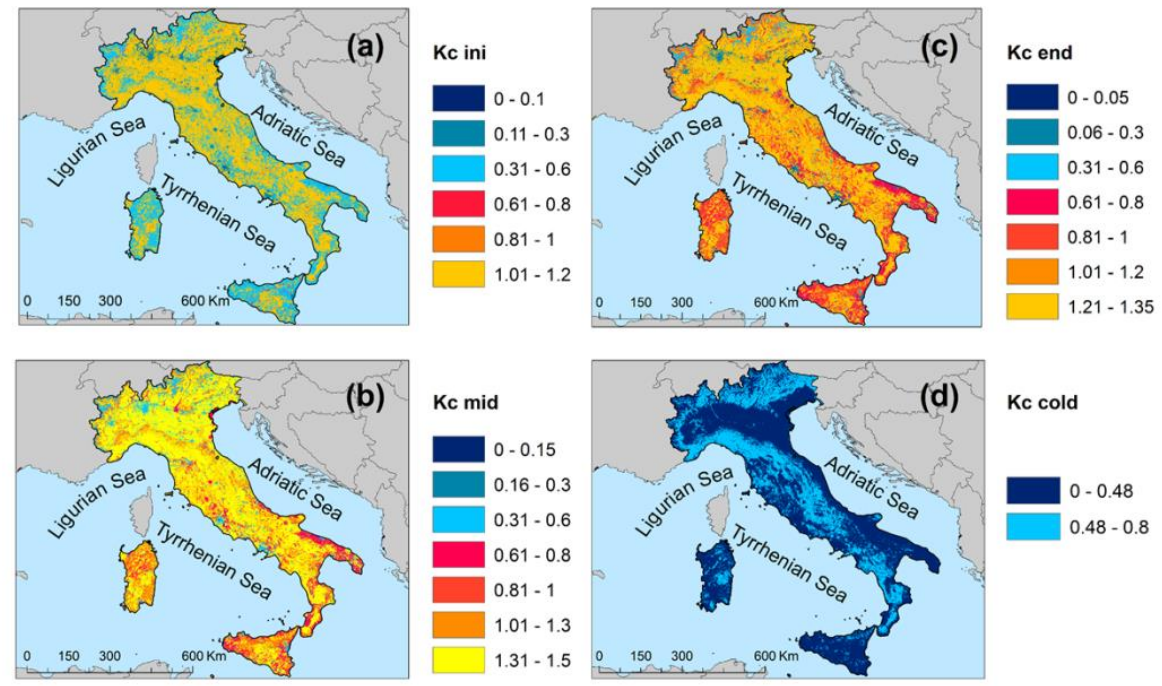

Fig. 7. Spatial distribution of $K_{c}$ in Italy related to the projection of scenario $B 1$. (a) $K_{c}$ ini for the initial season. (b) $K_{c}$ mid for the mid-season season. (c) $K_{c}$ end for the end season. 
(d) $\mathrm{K}_{\mathrm{c} \text { cold }}$ for the cold season.
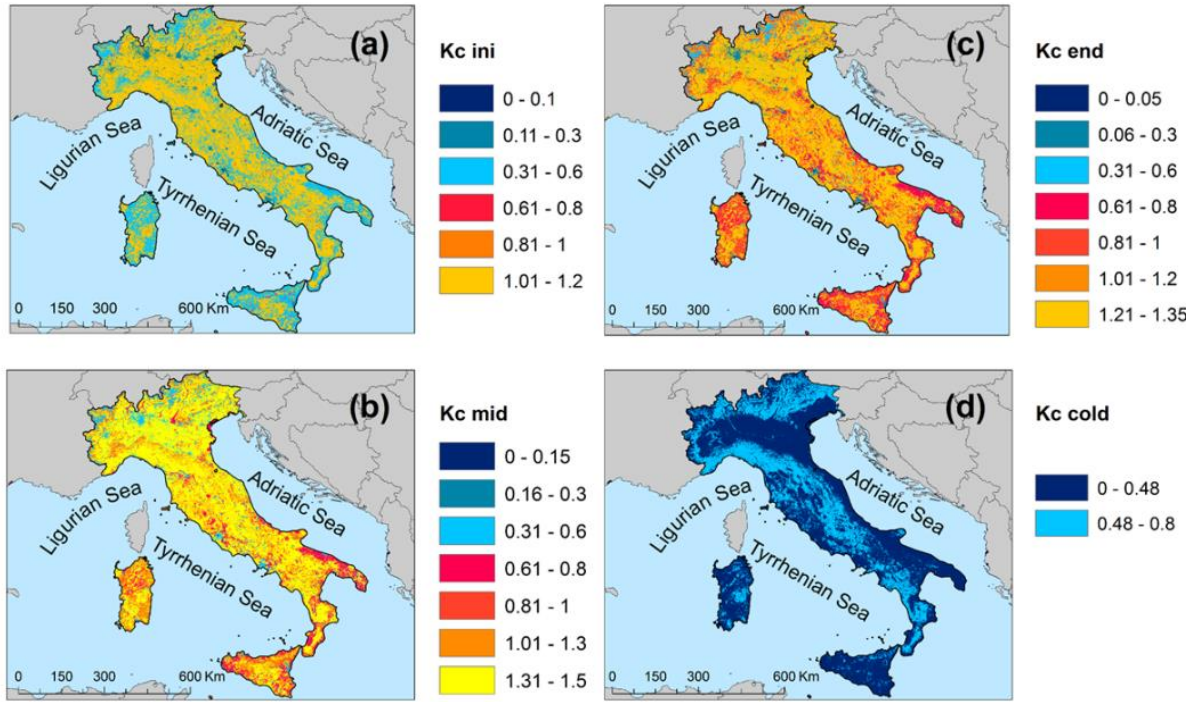

Kc cold

Fig. 8. Spatial distribution of $K_{c}$ in Italy related to the projection of scenario $B 2$. (a) $K_{c}$ ini for the initial season. (b) $K_{c}$ mid for the mid-season season. (c) $K_{c}$ end for the end season.

d) $\mathrm{K}_{\mathrm{c} \text { cold }}$ for the cold season.

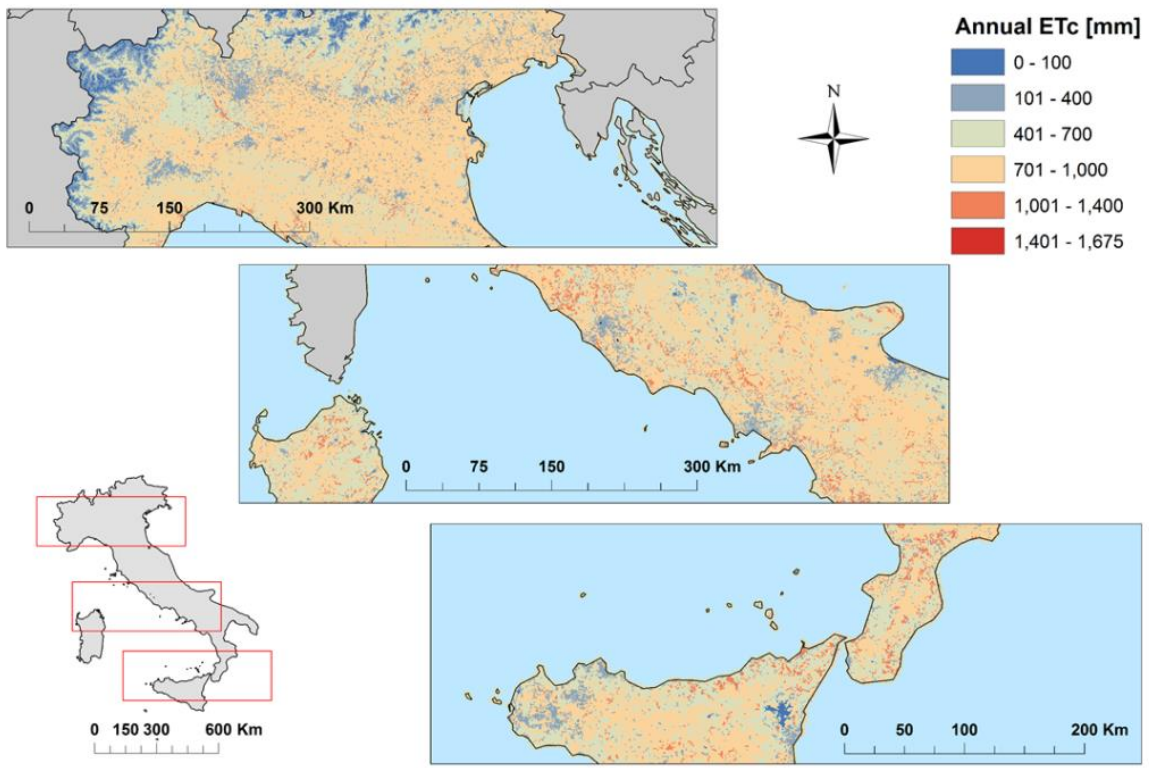

Fig. 9. Spatial distribution of annual $\mathrm{ET}_{\mathrm{c}}$ in Italy related to the present (details of three sides). 
Thus, in the mountain areas covered by forest and trees, the $\mathrm{K}_{\mathrm{c} \text { cold }}$ varies from 0.48 to 0.8 , while in the plains, coastal areas, urban areas, Sicily and almost whole territory of Sardinia the values are 0 . The pattern of $K_{c \text { ini }}, K_{c \text { mid }}, K_{c}$ end, and $K_{c}$ cold, are very similar for all scenarios. Figures $5-\mathbf{8}$ show the variation of $\mathrm{K}_{\mathrm{c}}$ in the Italian land considering the four seasons. Following the presented methodology, from the seasonal $\mathrm{ET}_{0}$ and seasonal $\mathrm{K}_{\mathrm{c}}$, the annual $\mathrm{ET}_{\mathrm{c}}$ was calculated for the present in aim to extract the $\mathrm{AK}_{\mathrm{c}}$. Figure 9 illustrates three sheets of Italian Peninsula where the annual $\mathrm{ET}_{\mathrm{c}}$ is more diversified and the values pattern can be observed in details.

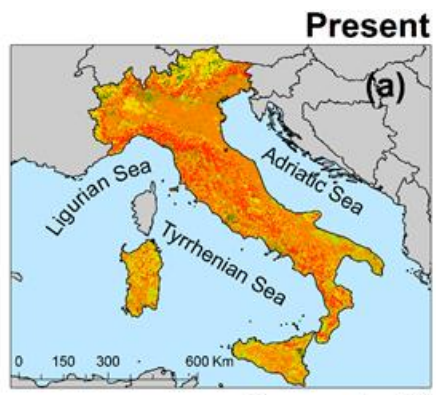

\section{Annual Kc}

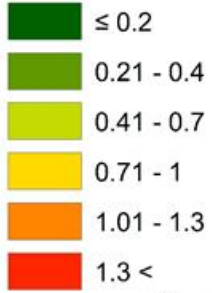

Scenario A1
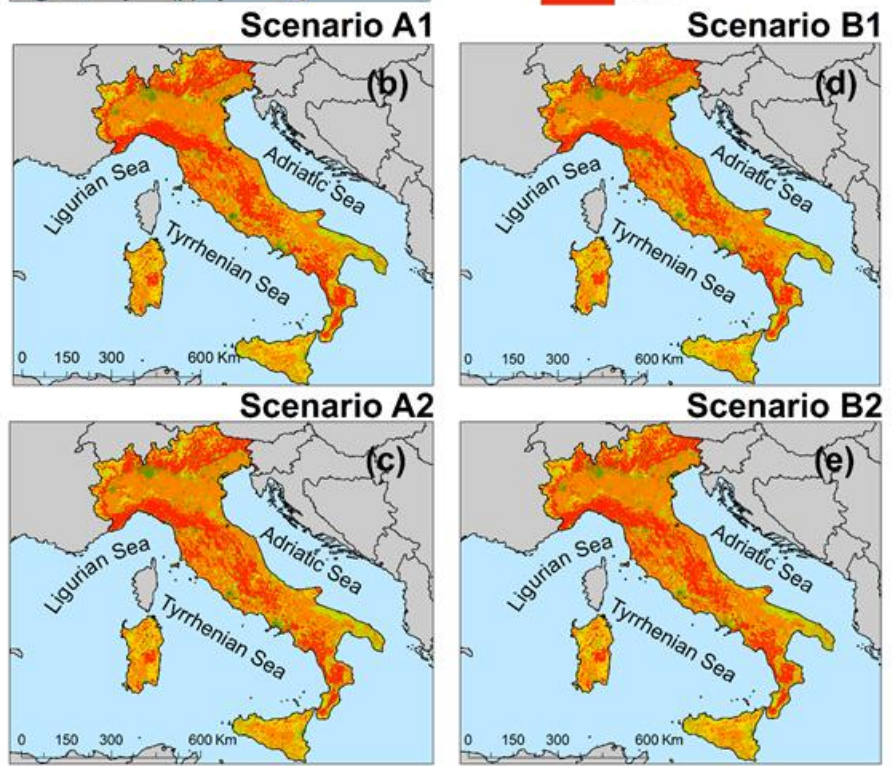

Fig. 10. Spatial distribution of $A K_{c}$ in Italy related to the present and future projection. (a) $A K_{c}$ for the present. (b) $\mathrm{AK}_{\mathrm{c}}$ for the Scenario A1. (c) $\mathrm{AK}_{\mathrm{c}}$ for scenario $\mathrm{A} 2$. (d) $\mathrm{AK}_{\mathrm{c}}$ for the scenario B1. (e) $\mathrm{AK}_{\mathrm{c}}$ for the scenario B2.

The annual $\mathrm{ET}_{\mathrm{c}}$ ranges from 0 to $1675 \mathrm{~mm}$, indicating the lowest values (below 400 $\mathrm{mm}$ ) in the mountain areas, in the urban and in the no vegetated areas. The high values of annual $\mathrm{ET}_{\mathrm{c}}$ were depicted in the all three set sheets, especially in many sides of the North, 
central and South of Italy, where the ferest area is located. After the ratio of $\mathrm{ET}_{\mathrm{c}}$ and $\mathrm{ET}_{0}$, the $\mathrm{AK}_{\mathrm{c}}$ have been calculated for Italy using the present climate and land cover layers.

Figure 10 depicts the $\mathrm{AK}_{\mathrm{c}}$ spatial distribution for the present and future. Few territories has low values of $\mathrm{AK}_{\mathrm{c}}$ (below 0.2) and are located in the North of Italy, some sides of Tyrrhenian coast, and in the agglomerated urban areas. The highest values (above 1.3) of the $\mathrm{AK}_{\mathrm{c}}$ could be found in the Alps and Apennines Ranges while in the plains, and coastal areas the values of $\mathrm{AK}_{\mathrm{c}}$ varies from 1 to 1.3. The southeastern part of Italy, western and eastern parts of Sicily, the $\mathrm{AK}_{\mathrm{c}}$ has values between 0.4 and 0.7. Table 3 reports the calibrated values of $\mathrm{AK}_{\mathrm{c}}$ for the present and Table 4 reports the $\mathrm{AK}_{\mathrm{c}}$ for the future.

\section{DISCUSSION AND CONCLUSIONS}

Spatial distribution of seasonal $\mathrm{K}_{\mathrm{c}}$ in Italy have been mapped for the present and future period. From the annual $\mathrm{ET}_{\mathrm{c}}$ calculation, the $\mathrm{AK}_{\mathrm{c}}$ specified for all classes of land cover was found. Due to the detailed division of CORINE Land Cover up to $4^{\text {th }}$ level, the present $\mathrm{AK}_{\mathrm{c}}$ map illustrates a distribution of crops presence mare diversified than in the future scenarios. In all cases, the high values of $\mathrm{AK}_{\mathrm{c}}$ extends in the North of Italy, more precise in Prealps areas between Po Plain and Alps, in the Northern and Central Apennines, where the forest and the crops with evapotranspiration capacity rate rise over 1.3, but also in some sides of the South of Italy, Sicily and Sardinia. The lower $\mathrm{AK}_{\mathrm{c}}$ (below 0.4) were depicted din the high mountains areas and surrounding the big cities.

Under the land cover projections, the land with high values of $\mathrm{AK}_{\mathrm{c}}$ extends up to 2040, the scenario A1 is the most alarming for the Italian territory. Is the evolution of land cover will follow this scenario, the direct negative effects on agriculture and water resources will affected due to the irrigation water quantity requires.

Our work has obvious some limitations, not really from the calculation survey but more related to some aspects of missing field measurements. The complex land of Italy and the spatial extension no not allow us to complete an exhaustive study by tensiometers and lysimeters. For the same reason, in the Thornthwaite equation, the latitude factor of sunshine was set at 1 . These limitations doesn't affects the investigations considering the large scale of the study, but also the appropriate results carried out here are in range with other studies about $\mathrm{K}_{\mathrm{c}}$ and $\mathrm{ET}_{\mathrm{c}}$ in central and southern Europe.

Present and future maps of seasonal $\mathrm{K}_{\mathrm{c}}$ and $\mathrm{AK}_{\mathrm{c}}$ at spatial scale of Italy represent significant tools for climatologists and hydrogeologists from one of the larger and complex country from Europe. Based on these maps, the water deficit and water surplus for different locations of the country may be calculated.

\section{Acknowledgements}

The authors would like to thank to the Copernicus Land Monitoring Services, which provided the land cover data for the present study. Many thanks are welcome to Andreas Hamann from Alberta University for all support during the research and for the climate data models provided. The second affiliation of the author is Earthresearch Company, Department of Hydrogeology, Cluj-Napoca, Romania. 
Table 3. Corine Land Cover classes and annual Kc calculated for present in Italy.

\begin{tabular}{|c|c|c|c|c|c|c|}
\hline & Corine Land Cover & & & c annu & & \\
\hline $\begin{array}{l}\text { CLC code } \\
2012 \\
\end{array}$ & CLC Description & $\mathrm{Kc}$ & $\mathrm{Ks}$ & $\mathrm{Ku}$ & $\mathrm{Kw}$ & Kclc \\
\hline 111 & Continous urban fabric & - & - & 0.29 & - & 0.29 \\
\hline 112 & Discontinuous urban fabric & - & - & 0.21 & - & 0.21 \\
\hline 121 & Industrial or commercial units & - & - & 0.3 & - & 0.3 \\
\hline 122 & Road and rail networks and associated land & - & - & 0.25 & - & 0.25 \\
\hline 123 & Port areas & - & - & 0.39 & - & 0.39 \\
\hline 124 & Airports & - & - & 0.3 & - & 0.3 \\
\hline 131 & Mineral extraction sites & - & - & 0.26 & - & 0.26 \\
\hline 132 & Dump sites & - & - & 0.26 & - & 0.26 \\
\hline 133 & Construction sites & - & - & 0.26 & - & 0.26 \\
\hline 141 & Green urban areas & - & - & 0.21 & - & 0.21 \\
\hline 142 & Sport and leisure facilities & - & - & 0.21 & - & 0.21 \\
\hline 211 & Non-irrigated arable land & 1.14 & - & - & - & 1.14 \\
\hline 212 & Permanently irrigated land & 1.25 & - & - & - & 1.25 \\
\hline 213 & Rice fields & 0.94 & - & - & - & 0.94 \\
\hline 221 & Vineyards & 0.5 & - & - & - & 0.5 \\
\hline 222 & Fruit trees and berry plantations & 0.68 & - & - & - & 0.68 \\
\hline 223 & Olive groves & 0.66 & - & - & - & 0.66 \\
\hline 231 & Pastures & 0.7 & - & - & - & 0.7 \\
\hline 241 & Annual crops associated with permanent crof & 0.67 & - & - & - & 0.67 \\
\hline 242 & Complex cultivation patterns & 1.16 & - & - & - & 1.16 \\
\hline 243 & $\begin{array}{l}\text { Land principally occupied by agriculture, } \\
\text { with significant areas of natural vegetation }\end{array}$ & 0.92 & - & - & - & 0.92 \\
\hline 244 & Agro-forestry areas & 0.92 & - & - & - & 0.92 \\
\hline 311 & Broad-leaved forest & 1.42 & - & - & - & 1.42 \\
\hline 312 & Coniferous forest & 1 & - & - & - & 1 \\
\hline 313 & Mixed forest & 1.33 & - & - & - & 1.33 \\
\hline 321 & Natural grasslands & 0.97 & - & - & - & 0.97 \\
\hline 322 & Moors and heathland & 0.92 & - & - & - & 0.92 \\
\hline 323 & Sclerophyllous vegetation & 0.62 & - & - & - & 0.62 \\
\hline 324 & Transitional woodland-shrub & 0.83 & - & - & - & 0.83 \\
\hline 331 & Beaches, dunes, sands & - & 0.23 & - & - & 0.23 \\
\hline 332 & Bare rocks & - & 0.15 & - & - & 0.15 \\
\hline 333 & Sparsely vegetated areas & 0.48 & - & - & - & 0.48 \\
\hline 334 & Burnt area & - & 0.1 & - & - & 0.1 \\
\hline 335 & Glaciers and perpetual snow & - & - & - & 0.5 & 0.51 \\
\hline 411 & Inland marshes & - & - & - & 0.5 & 0.45 \\
\hline 412 & Peat bogs & - & - & - & 0.4 & 0.37 \\
\hline 421 & Salt marshes & - & - & - & 0.3 & 0.32 \\
\hline 422 & Salines & - & 0.1 & - & - & 0.1 \\
\hline 423 & Intertidal flats & - & - & - & 0.6 & 0.64 \\
\hline 511 & Water courses & - & - & - & 0.6 & 0.63 \\
\hline 512 & Water bodies & - & - & - & 0.6 & 0.64 \\
\hline 521 & Coastal lagoons & - & - & - & 0.7 & 0.68 \\
\hline 522 & Estuaries & - & - & - & 0.6 & 0.62 \\
\hline 523 & Sea and ocean & - & - & - & 0.7 & 0.74 \\
\hline
\end{tabular}




\begin{tabular}{|c|c|c|c|c|c|c|c|}
\hline & & Corine Land Cover & & & $\mathrm{K}$ & & \\
\hline $\begin{array}{c}\text { CLC code } \\
2012\end{array}$ & $\begin{array}{l}\text { CLC } \\
\text { projection } \\
\text { code }\end{array}$ & CLC Des cription & $\mathrm{Kc}$ & $\mathrm{Ks}$ & $\mathrm{Ku}$ & $\mathrm{Kw}$ & $\mathrm{Kclc}$ \\
\hline 133 & 0 & B uilt-up area & - & - & 0.3 & - & 0.26 \\
\hline 211 & 1 & Arable land (non-irrigated) & 1.1 & - & - & - & 1.14 \\
\hline 231 & 2 & $\mathrm{P}$ as ture & 0.7 & - & - & - & 0.7 \\
\hline 321 and 324 & 3 & $\begin{array}{l}\text { Natural and semi-natural vegetation (including Natural } \\
\text { gras s lands, } s \text { crublands, regenerating forest below } 2 \mathrm{~m} \text {, and s mall } \\
\text { forest patches within agricultural lands capes) }\end{array}$ & 0.9 & - & - & - & 0.9 \\
\hline 411 & 4 & Inland we tlands & - & - & - & 0.45 & 0.45 \\
\hline 335 & 5 & Glaciers and snow & - & - & - & 0.51 & 0.51 \\
\hline 212 & 6 & Irrigated arable land & 1.3 & - & - & - & 1.25 \\
\hline 321 & 7 & $\begin{array}{l}\text { Recently abandoned arable land (i.e. "long fallow"; includes very } \\
\text { extens ive farmland not reported in agriculturals tatis tics, } \\
\text { herbaceous vegetation, grasses and shrubs below } 30 \mathrm{~cm} \text { ) }\end{array}$ & 1 & - & - & - & 0.97 \\
\hline 241 & 8 & Permanent $\mathrm{crops}$ & 0.7 & - & - & - & 0.67 \\
\hline 313 & 10 & Forest & 1.3 & - & - & - & 1.33 \\
\hline 333 & 11 & Spars ely vegetated areas & 0.5 & - & - & - & 0.48 \\
\hline 331 & 12 & Beaches, dunes and sands & - & 0.2 & - & - & 0.23 \\
\hline 422 & 13 & Sa lines & - & 0.1 & - & - & 0.1 \\
\hline 423 and 521 & 14 & Water and co as tal flats & - & - & - & 0.66 & 0.66 \\
\hline 322 & 15 & Heathland and moorlands & 0.9 & - & - & - & 0.92 \\
\hline 231 and 324 & 16 & pasture land not reported in agriculturals tatis tics, grasses and & 0.8 & - & - & - & 0.76 \\
\hline
\end{tabular}

\section{REFERENCES}

Adamo, F., De Capua, C., Filianoti, P., Lanzolla, A.M.L. \& Morello, R. (2014) A coastal erosion model to predict shoreline changes. Measurement, 47, 734-740.

Allen, R.G., Pereira, L.S., Raes, D. \& Smith, M. (1998) Crop Evapotranspiration: Guidelines for Computing Crop Water Requirements. FAO Irrigation and Drainage Paper 56. FAO: Rome, pp. 300.

Allen, R.G. (2000) Using the FAO-56 dual crop coefficient method over an irrigated region as part of an evapotranspiration intercomparison study. Journal of Hydrology, 229, 27-41.

Angelini, M.G., Costantino, D. \& Di Nisio, A. (2017) ASTER image for environmental monitoring: Change detection and thermal map. IEEE International Instrumentation and Measurement Technology Conference, Proceedings, 7969745.

Brouyère, S., Carabin, G. \& Dassargues, A. (2004) Climate change impacts on groundwater resources: modelled deficits in a chalky aquifer, Geer basin, Belgium. Hydrogeology Journal, 12, 123-134.

Campos, G.E.P., Moran, M.S., Huete, A., Zhang, Y., Bresloff, C., Huxman, T.E. et al. (2013) Ecosystem resilience despite large-scale altered hydroclimatic conditions. Nature, 494, 349-353.

Copernicus Land Monitoring Services. (2012) CORINE Land Cover of Europe. URL: http://land.copernicus.eu/ (accessed 21 July 2016).

European Environmental Agency. (2007) Land-use scenarios for Europe: qualitative and quantitative analysis on a European scale. ISSN 1725-2237. EEA Technical report No 9/2007. 
Gowda, P.H., Chavez, J.L., Colaizzi, P.D., Evett, S.R., Howell, T.A. \& Tolk, J.A. (2008) ET mapping for agricultural water management: present status and challenges. Irrigation Science, 26(3), 223237.

Grimmond, C.S.B. \& Oke, T.R. (1999) Evapotranspiration rates in urban areas, Impacts of Urban Growth on SurfaceWater and Groundwater Quality. Proceedings of IUGG 99 Symposium HSS. Birmingham, July 1999.

Hamann, A., Wang, T., Spittlehouse, D.L. \& Murdock, T.Q. (2013) A comprehensive, high-resolution database of historical and projected climate surfaces for western North America. Bulletin of the American Meteorological Society, 94, 1307-1309.

Kottek, M., Grieser, J., Beck, C., Rudolf, B. \& Rubel, F. (2006) World Map of the Köppen-Geiger climate classification updated. Meteorologische Zeitschrift, 15(3), 259-263.

Li, K.Y., Coe, M.T., Ramankutty, N. \& De Jong, R. (2007) Modeling the hydrological impact of landuse change in West Africa. Journal of Hydrology, 337, 258-268.

Loàiciga, H.A., Maidment, D.R. \& Valdes, J.B. (2000) Climate-change impacts in a regional karst aquifer, Texas, USA. Journal of Hydrology, 227, 173-194.

Nistor, M.M., Cheval, S., Gualtieri, A., Dumitrescu, A., Boţan, V.E., Berni, A., Hognogi, G., Irimuş, I.A. \& Porumb-Ghiurco, C.G. (2017) Crop evapotranspiration assessment under climate change in the Pannonian basin during 1991-2050. Meteorol. Appl., 24, 84-91.

Parmesan, C. \& Yohe, G. (2003) A globally coherent fingerprint of climate change impacts across natural systems. Nature, 421(2), 37-42.

Prăvălie, R., Sîrodoev, I. \& Peptenatu, D. (2014) Detecting climate change effects on forest ecosystems in Southwestern Romania using Landsat TM NDVI data. Journal of Geographical Sciences, 24, 815-832.

Rogan, J. \& Chen, D.M. (2004) Remote sensing technology for mapping and monitoring land-cover and land-use change. Progress in Planning, 61(4), 301-325.

Rosenberry, D.O., Winter, T.C., Buso, D.C. \& Likens, G.E. (2007) Comparison of 15 evaporation methods applied to a small mountain lake in the northeastern USA. Journal of Hydrology, 340, 149-166.

Schulp, C.J.E., Tieskens, K.F., Sturck, J., Fuchs, R., van der Zanden, E.H., Schrammeijer, E. \& Verburg, P.H. (2015) EU scale analysis of future cultural landscape dynamics. Report no. 1, WP 5 Fine- and broad-scale modelling of future landscapes.

Thornthwaite, C.W. (1948) An approach toward a rational classification of climate. Geogr. Rev., 38, 55-94.

Treitz, P. \& Rogan, J. (2004) Remote sensing for mapping and monitoring land-cover and land-use change - an introduction. Progress in Planning, 61, 269-279. 